\title{
On the Latest Development Trend of Foreign Electric Power Market and Its Implications
}

\author{
Jiawei Wang ${ }^{1, \text { a }}$ \\ ${ }^{1}$ North China Electric Power University, Beijing 102206, China \\ a1462897130@qq.com
}

Keywords: foreign electric power market; development trend; implication

\begin{abstract}
With rapid economic and social development, the electric power market in China has made great progress in recent years. But since there is a large gap between electric power market in China and developed countries, the development trend of electric power market in developed countries tends to bring unusual implications to the development of electric power market in China. For this end, in this paper, we carry out a specific study on the latest development trend of foreign electric power market and its implications. Hopefully, our study can be of certain help to the better development of electric power industry in China.
\end{abstract}

\section{Introduction}

Under the influence of a variety of challenges and reforms, such as international financial crises, nuclear accidents, global climate changes and development of clean energy, electric power market mechanisms and supporting policies in developed countries have always been reformed in recent years. On this basis, all kinds of explorations bring sufficient implications to the development of electric power market in China. To sort out the development rules of international electric power market and ensure that the electric power market in China wins more powerful support is the reason why we carry out a specific study on the latest development trend of foreign electric power market and its implications.

\section{Basic Modes of Foreign Electric Power Market}

On foreign electric power market, two of the most common and basic modes are wholesale market competition and deregulation on sales-side. Here, wholesale market competition itself can be divided into two types, centralized trade and decentralized trade. With this knowledge, Tab. 1 visualizes wholesale market competition.

Tab. 1 Wholesale Market Competition

\begin{tabular}{|c|c|c|}
\hline Mode & Typical Country & Characteristic \\
\hline Centralized Trade & $\begin{array}{l}\text { United States and } \\
\text { Australia }\end{array}$ & $\begin{array}{l}\text { A centralized optimization method is adopted, to realize organic integration } \\
\text { between power dispatching and trading agencies; }\end{array}$ \\
\hline Decentralized Trade & EU countries; & $\begin{array}{l}\text { The trade is simple. But there are high requirements for cohesion and } \\
\text { coordination. It fits into the characteristic of EU countries with numerous } \\
\text { subjects. }\end{array}$ \\
\hline
\end{tabular}

With a simple knowledge of wholesale market competition, as a basic mode of foreign electric power market, we also need to clarify deregulation on sales-side. In an actual survey conducted by the author, it is commonplace in foreign countries that options of industrial and commercial users, etc. are deregulated. But in New Zealand and other countries, options are deregulated selectively, from small to large, which warrants our attention.

\section{The Latest Development of Foreign Electric Power Market}

With a simple knowledge of basic modes of foreign electric power market, we also need to analyze the latest development of foreign electric power market in depth. Combined with literature review and the author's actual survey, the discussion in this section will focus on three aspects, i.e., the 
building of large-scale trans-regional and trans-national electric power market, the rapid development of renewable energy and reinforcement of effective supervision, etc.

2.1 The building of large-scale trans-regional and trans-national electric power market

For the building of large-scale trans-regional and trans-national electric power market, it emerged as a result of the progress of power transmission technology and rapid development of renewable energy. In 2010, the United States advocated expanding the regional electric power market. This was the source of the building of large-scale trans-regional and trans-national electric power market. In the EU, the unification of energy market also falls into the category of the building of large-scale trans-regional and trans-national electric power market. Qijiang District implemented uniform power trade and prices. Tab. 2 visualizes the main process of electric power market combination in EU countries. From this table, we can gain a deep insight into the building of large-scale trans-regional and trans-national electric power market [1].

Tab. 2 The Main Process of Electric Power Market Combination in EU Countries

\begin{tabular}{ll}
\hline Time & Milestone \\
\hline 2009 & Czech Republic and Slovakia realized intraday market combination; \\
2011 & Two of the largest short-term power pools in Europe announced to establish a joint trading platform; \\
2013 & The bidding area in Nord Pool Spot expanded; \\
2014 & Several power pools in the EU achieved day-ahead market clearing jointly; \\
\hline
\end{tabular}

2.2The rapid development of renewable energy

Although renewable energy economy has not yet fully surpassed conventional energy, various advantages of renewable energy begin to be valued by many developed countries. Fig. 1 shows common renewable energy. To ensure that this kind of renewable energy can achieve rapid development, many foreign countries adopt renewable energy incentives. Tab. 3 visualizes such incentives.

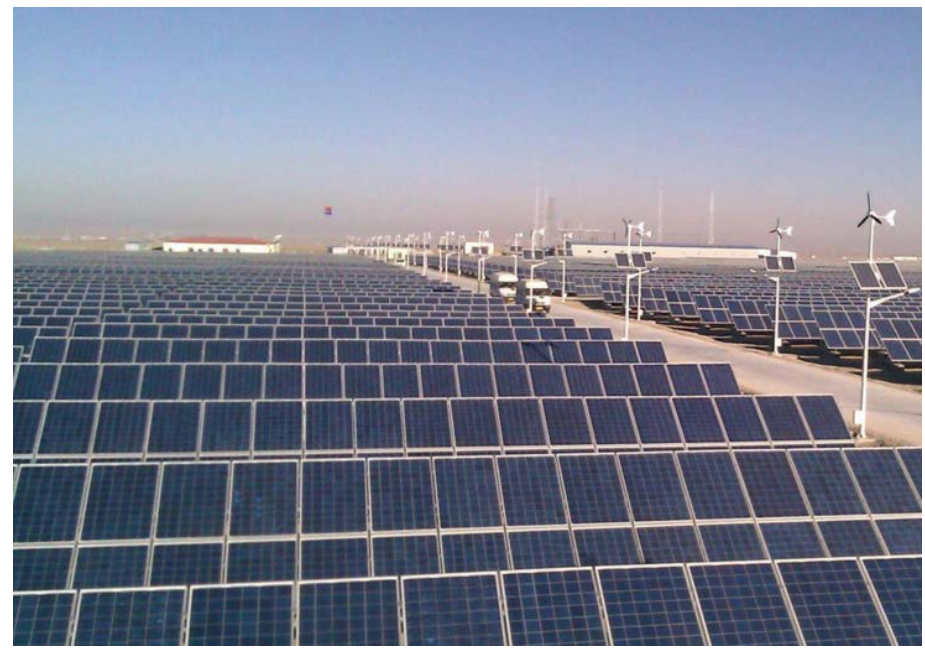

Fig. 1 Schematic of Renewable Energy

Tab. 3 Common Renewable Energy Incentives in Foreign Countries

\begin{tabular}{|c|c|c|}
\hline Incentive & Typical Country & Detailed Description \\
\hline Fixed electricity price & Germany and Japan & $\begin{array}{l}\text { The government gives subsidies after clarifying the power generation } \\
\text { price of renewable energy; }\end{array}$ \\
\hline $\begin{array}{c}\text { Subscription of green } \\
\text { power }\end{array}$ & Netherlands & The government quotes and energy consumers subscribe; \\
\hline Quota of renewable energy & $\begin{array}{l}\text { United States and } \\
\text { United Kingdom }\end{array}$ & $\begin{array}{l}\text { It is provided that suppliers should provide part of renewable energy. The } \\
\text { price is subject to the market. }\end{array}$ \\
\hline
\end{tabular}

\subsection{Reinforcement of effective supervision}

Apart from the above aspects, the reinforcement of effective supervision is also the latest development trend of foreign electric power market. This kind of reinforcement is mainly to strengthen government supervision, improve supervisory methods and guarantee market equity. Tab. 4 visualizes common means of effective supervision in foreign countries in recent years [2]. 
Tab. 4 Common Means of Effective Supervision in Foreign Countries

\begin{tabular}{ll}
\hline Country & \multicolumn{1}{c}{ Means } \\
\hline Australia & In 2012, Australia proposed to reform and implement a reasonable return rate of power grid \\
& business \\
United States & In 2012, the United States promulgated rules on disclosure of electric power market information; \\
United Kingdom & $\begin{array}{l}\text { In 2010, the United Kingdom proposed to build a new sustainable power network supervision } \\
\text { model; }\end{array}$ \\
\hline
\end{tabular}

\section{Implications of International Experience for China}

Combined with the above content, we are able to understand the latest development trend of foreign electric power market in recent years intuitively. Domestic electric power market can get some implications to promote its own development. Tab. 5 visualizes these implications. From this table, we can gain a deep insight into the focus of this study.

Tab. 5 Implications of International Experience for China

\begin{tabular}{ll}
\hline \multicolumn{1}{c}{ Implication } & \multicolumn{1}{c}{ Content } \\
\hline $\begin{array}{l}\text { External environment and conditions } \\
\text { directly concern the development of } \\
\text { electric power market. }\end{array}$ & $\begin{array}{l}\text { We need to build a scientific electricity price system, a strong power grid and a } \\
\text { supervisory system adaptable to the market. Only in this way can we offer powerful } \\
\text { support to the better development of electric power market; }\end{array}$ \\
$\begin{array}{ll}\text { With sustainable development as the } \\
\text { goal }\end{array}$ & $\begin{array}{l}\text { To realize the benign and sustainable development of electric power market, combined } \\
\text { with social construction, ecological construction and development of clean energy; } \\
\text { To gradually deregulate users' options } \\
\text { To deregulate users’ options and perfect the competition mechanism of electric power } \\
\text { market; }\end{array}$ \\
\hline
\end{tabular}

\section{Conclusion}

In the present study on the latest development trend of foreign electric power market and its implications, the author elaborates on basic modes of foreign electric power market, state of the art of foreign electric power market and implications of international experience for China. Hopefully, this paper can bring some inspirations to the development of electric power market in China.

\section{References}

[1]Conejo A J, Contreras J, Arroyo J M, et al. Optimal response of an oligopolistic generating company to a competitive pool-based electric power market[J]. IEEE Transactions on Power Systems, 2002, 17(2):424-430.

[2]Pritchard G, Zakeri G, Philpott A. A Single-Settlement, Energy-Only Electric Power Market for Unpredictable and Intermittent Participants.[J]. Operations Research, 2010, 58(4):1210-1219. 